\title{
Response of Easter Lily Bulbs to Peat Moisture Content and the Use of Peat or of Polyethylene- lined Cases during Handling and Vernalization
}

\author{
Timothy A. Prince ${ }^{1}$ and Maria S. Cunningham ${ }^{2}$ \\ Department of Horticulture, Ohio Agricultural Research and Development Center, The Ohio State \\ University, Columbus, $\mathrm{OH} 43210$ \\ Additional index words. Lilium longiflorum, potted flowering plants, forcing
}

\begin{abstract}
Lining of shipping cases with low-density polyethylene (PE) greatly reduced moisture loss from packing media and bulbs of Lilium longjlorum Thunb. 'Nellie White' during shipping, handling, and case vernalization (CV). Three years of studies showed that use of PE liners accelerated floral sprout emergence above the growing medium, floral bud initiation, and flowering date. Effects of case lining became more pronounced as the initial water content of the spagnum peat packing was lowered. Case lining sometimes increased apical meristem diameters measured immediately after vernalization, or 2 or 4 weeks after bulb planting, but flower bud number was never significantly increased. Root growth during the first 4 weeks after planting was not affected by case lining. Bulb scale and basal plate water contents at planting were greater in lined than nonlined cases and when packed in peat of relatively high moisture content. Handling and vernalization of bulbs in PE-lined cases without a packing medium resulted in similar bulb forcing characteristics as in bulbs held in PE-lined cases packed with sphagnum peat.
\end{abstract}

Six weeks of cold exposure is used to accelerate flowering and reduce the spread in days to flower of lily bulbs used for Easter forcing (De Hertogh and Wilkins, 1971a, 1971b). The two major methods used to cold-treat lily bulbs are case vernalization (CV) and controlled temperature forcing (CTF) (Wilkins, 1976, 1977; De Hertogh et al., 1969). CV involves providing 6 weeks of cold exposure to bulbs while packed in moist sphagnum peat in shipping cases. CTF involves potting of the bulbs and allowing a period of root growth at $17 \mathrm{C}$ before vernalization. Apical meristem diameter, flower bud number (De Hertogh et al., 1976), leaf number (Yang et al., 1970), and length of bottom leaves (Blaney and Roberts, 1967) decrease as the duration at which bulbs are held at vernalizing temperatures increases. The industry standard of 6 weeks of cold is, therefore, a compromise that yields acceptable acceleration of flowering with only moderate reduction of flower number.

Most researchers have agreed that moisture in the packing peat is critical for proper CV. Laiche and Box (1970) found cooling bulbs in sphagnum peat with $68 \%$ moisture (w/w) was equivalent to 2 additional weeks of cold treatment for bulbs in sphagnum peat with only $8 \%$ moisture. Stuart (1954) reported that cases of bulbs lose moisture during handling, but that packing with sphagnum peat at $40 \%$ to $45 \%$ moisture (w/w) in polyethylene- (PE) lined cases would avoid rots, yield more flowers, and allow for earlier flowering. His study, however, was not properly replicated, nor did he use vernalizing temperature common in the industry today.

We attempt here to expand upon Stuart's findings with 3 years of studies aimed at improving CV methodology for Easter lily bulbs. The studies further examined the influence of peat mois-

\footnotetext{
Received for publication 3 Oct. 1988. Salaries and research support provided by state and federal funds appropriated to the Ohio Agricultural Research and Development Center, The Ohio State Univ. Manuscript 251-88. We thank the Fred C. Gloeckner Foundation and Hastings Bulb Growers for their financial support of this research. We also acknowledge the technical assistance of Lee Riddle, Easter Lily Research Foundation. The cost of publishing this paper was defrayed in part by the payment of page charges. Under postal regulations, this paper therefore must be hereby marked advertisement solely to indicate this fact.

'Assistant Professor.

${ }^{2}$ Research Technician
}

ture content, and the use of peat and of PE-case liners on the responses of bulbs to $\mathrm{CV}$.

\section{Materials and Methods}

General procedures. Studies were conducted during the forcing seasons of 1985-86 through 1987-88. Bulbs of 'Nellie White' ( 23 to $25 \mathrm{~cm}$ in circumference) were produced in Oregon, harvested in late September, packed in cases according to treatments, and held in warehouse storage at 13 to $18 \mathrm{C}$ for 2 to 4 weeks before shipping. Packing was in standard industry corrugated fiberboard-veneered wooden cases $(38 \times 30 \times 63 \mathrm{~cm})$ designed to hold 150 bulbs. In cases where peat was used, small plastic mesh bags of the medium were inserted in place of five bulbs in the case to allow for rapid removal of samples for moisture determination during the experiment. Sphagnum peat water content was determined by oven-drying samples at packing and after CV. Containers were lined with $0.04-\mathrm{mm}$-thick low-density PE that was loosely folded over at the top of cases. Liners were not sealed. Cases were shipped to Columbus, Ohio (4 to 6 days) in refrigerated trucks. CV was for 6 weeks at 4 to 5C at commercial facilities (1985-86 and 1986-87) or at the Dept. of Horticulture, The Ohio State Univ. (1987-88). Temperatures were monitored regularly at both locations.

Following vernalization treatments, the bulbs were planted in 1.4-liter pots containing Metro-Mix 350 (W.R. Grace, Cambridge, Mass.) immediately or after $24 \mathrm{hr}$ of holding at $22 \mathrm{C}$ (1987-88). Planting dates were 21 Nov. 1985, 8 Dec. 1986, and 1 Dec. 1987. Bulbs were forced according to standard commercial practice (De Hertogh, 1985). Air minima at night were maintained at $15.5 \mathrm{C}$ The maximum for the growing medium was $18.5 \mathrm{C}$ during rooting and floral initiation. Greenhouse ventilation began at $21 \mathrm{C}$ after floral initiation. Where indicated below, apical meristem diameters were determined as described by De Hertogh et al. (1976), from which we adapted a 6-point rating scale for developmental stage: 1) vegetative, 2) prefloral (doming), 3) four floral primordia visible (considered reproductive), 4) four flower buds formed with most advanced at stage $\left.P_{1}, 5\right)$ four flower buds formed with most advanced at stage $\mathrm{A}^{1-2}$, and 6) five to six flower buds formed with most advanced post-stage $\mathrm{G}$. 
The experimental unit was one case of bulbs, with two replicate cases used for each treatment combination in a completely randomized design for all studies. The mean response of the multible-bulb subsamples from each case was calculated and subjected to analysis of variance. Quantitative trend and qualitative orthogonal contrasts were used for further elucidation of effects. Where quantitative variables were unequally spaced, orthogonal polynomials were constructed using the matrix procedure of SAS (SAS Institute, 1982). Least significant difference values were also calculated to aid in mean separation.

1985-86 studies. Bulbs were packed in sphagnum peat at $45 \%, 71 \%$, and $77 \%$ water content $(\mathrm{w} / \mathrm{w})$ in a factorial arrangement with or without a PE case liner. Five bulbs per case were sampled after $\mathrm{CV}$ for determination of water content, while 20 bulbs from each case were planted for forcing. Average days until emergence (above the growing medium), days until flowering (opening of first bud), and spread of first to last bulb shoot from a case to emerge and flower were recorded. Also observed

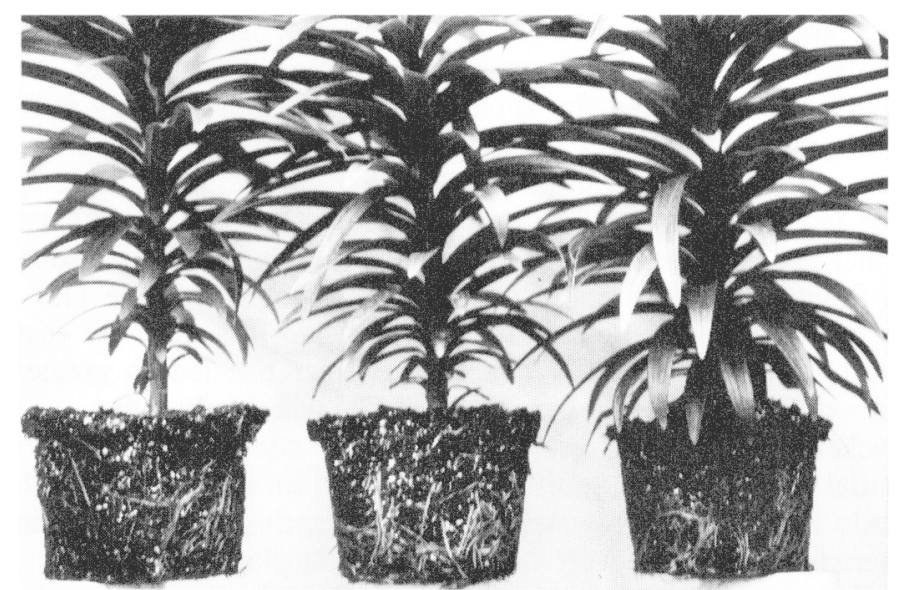

Fig. 1. Representative Easter lily plants used for visual rating of basal leaf elongation at flowering. Ratings were (left to right): 1) short, stubby leaves; 2) medium-length leaves; and 3) long leaves extending over pot rim. on the date of flower were total flower bud count, stem diameter just above the planting media, number of leaves, and a 1 to 3 basal leaf rating assigned each plant as 1) short stubby leaves, 2) medium-length leaves, or 3 ) long leaves (extending over pot rim). A photograph of representative plants of each rating was maintained for standardization of the rating scale. (Fig. 1)

1986-87 studies. Treatments of two sphagnum peat moisture levels, $76 \%$ and $51 \%$ water content, in a factorial arrangement with and without a PE liner were used. Ten total bulbs at packing as well as 10 bulbs from each case at planting were sampled for determination of living root fresh weight, water content of scales and basal plate, sprout length (length from meristematic mantle to point of attachment to basal plate), and apical meristem diameter and developmental stage. Fifty bulbs from each case were planted. At 2 and 4 weeks after planting, 10 bulbs per replicate were removed from their pots and washed free of growing medium for determination of new root fresh weight and presence of stem roots. Bulbs were then dissected for determination of sprout length, apical meristem diameter, and meristem developmental stage. The emergence and flowering of the 30 remaining bulbs planted from each case were evaluated as in $1985-86$.

1987-88. Bulbs were packed in sphagnum peat at $29 \%$ water (w/w) with a PE liner, at $68 \%$ water content without a PE liner, or in a PE line alone without packing medium. For the latter treatment, a 3 -cm layer of styrofoam "peanuts" $(\approx 4 \times 1.5$ $\mathrm{cm})$ were placed in the cases before lining and on top of the liner after folding to protect the bulbs from impacts during shipping and handling. A total of 10 bulbs was sampled at packing and five per case were sampled after CV and 2 and 4 weeks after planting for measurements as in 1986-87. In lieu of fresh weight determination, root growth was evaluated with a visual 0 to 6 scale. Representative samples of bulbs assigned each rating indicated average root fresh weights of 0$) 0$; 1) 0.12 ;2) 0.45 ; 3) 0.83 ; 4) 1.25 ; 5) 2.8 ; and 6) $4.2 \mathrm{~g}$.

\section{Results}

1985-86 studies. The use of the PE liner reduced water loss from the sphagnum peat during handling and $\mathrm{CV}$ to $\approx 2 \%$ (Table

Table 1. Influence of sphagnum peat moisture level and polyethylene case lining during handling and case vernalization on the response of 'Nellie White' Easter lily bulbs (1985-86).

\begin{tabular}{|c|c|c|c|c|c|c|c|c|c|}
\hline \multirow{2}{*}{$\begin{array}{c}\text { Initial sphagnum } \\
\text { peat water } \\
\text { content } \\
(\% \text { total wt) }\end{array}$} & \multirow[b]{2}{*}{$\begin{array}{c}\text { Case } \\
\text { lining }\end{array}$} & \multicolumn{2}{|c|}{$\begin{array}{c}\text { Water content at } \\
\text { planting } \\
(\% \text { total wt }) \\
\end{array}$} & \multicolumn{2}{|c|}{$\begin{array}{c}\text { Days to } \\
\text { emergence }\end{array}$} & \multirow{2}{*}{$\begin{array}{l}\text { Days } \\
\text { to } \\
\text { flower }\end{array}$} & \multirow{2}{*}{$\begin{array}{l}\text { Stem } \\
\text { diam } \\
(\mathrm{cm})\end{array}$} & \multirow{2}{*}{$\begin{array}{c}\text { Basal } \\
\text { leaf } \\
\text { ratingy }\end{array}$} & \multirow{2}{*}{$\begin{array}{l}\text { Flower } \\
\text { bud } \\
\text { number }\end{array}$} \\
\hline & & $\begin{array}{l}\text { Sphagnum } \\
\text { peat }\end{array}$ & Bulb & $\frac{\text { ems }}{\text { Mean }}$ & $\frac{\text { gence }}{\text { Spread }^{z}}$ & & & & \\
\hline 45 & Yes & 44 & 64.0 & 26 & 10.5 & 120 & 1.67 & 2.4 & 5.2 \\
\hline 71 & & 68 & 64.5 & 25 & 10.5 & 118 & 1.69 & 2.4 & 5.5 \\
\hline 77 & & 76 & 65.0 & 25 & 12.5 & 123 & 1.69 & 2.4 & 5.6 \\
\hline 45 & No & 34 & 63.5 & 28 & 14.0 & 125 & 1.59 & 2.2 & 5.2 \\
\hline 71 & & 64 & 64.5 & 25 & 10.0 & 119 & 1.63 & 2.1 & 5.0 \\
\hline 77 & & 73 & 65.5 & 25 & 13.5 & 120 & 1.64 & 2.0 & 5.4 \\
\hline LSD $(0.05)$ & & 3 & 1.2 & 3 & 1.7 & 12 & 0.07 & 0.5 & 0.5 \\
\hline \multicolumn{10}{|l|}{$F$ tests } \\
\hline Percent water & & $\mathrm{L}^{* * *}$ & $\mathrm{~L}^{* *}$ & $\mathrm{~L}^{*}$ & $\mathrm{Q}^{* * *}$ & NS & NS & NS & NS \\
\hline Liner & & $* * *$ & NS & NS & ** & NS & $*$ & * & NS \\
\hline Water $\times$ liner & & $\mathrm{L}^{* *}$ & NS & NS & $\mathrm{L}^{* *} \mathrm{Q}^{*}$ & NS & NS & NS & NS \\
\hline
\end{tabular}

${ }^{2}$ Days from first to last plant to emerge above the growing medium line.

'See Fig. 1.

$* * *, * *, *, N S P=0.001,0.01,0.05$, or nonsignificant, respectively. Response to increased initial medium water content is linear (L) or quadratic (Q). 
Table 2. Influence of peat moisture level and polyethylene case lining during handling and case vernalization on 'Nellie White' Easter lily bulb characteristics at planting (1986-87).

\begin{tabular}{|c|c|c|c|c|c|c|}
\hline \multirow{2}{*}{$\begin{array}{c}\text { Initial sphagnum } \\
\text { peat } \\
\text { water content } \\
\text { (\% total wt) }\end{array}$} & \multirow{2}{*}{$\begin{array}{l}\text { Case } \\
\text { lining }\end{array}$} & \multirow{2}{*}{$\begin{array}{c}\text { Final sphagnum } \\
\text { peat } \\
\text { water content } \\
(\% \text { total wt })\end{array}$} & \multirow{2}{*}{$\begin{array}{l}\text { Root } \\
\text { fresh } \\
\text { wt } \\
(\mathrm{g})\end{array}$} & \multicolumn{2}{|c|}{$\begin{array}{l}\text { Water contents } \\
\text { (\% fresh wt) }\end{array}$} & \multirow{2}{*}{$\begin{array}{l}\text { Meristem } \\
\text { diam } \\
(\mathrm{mm})\end{array}$} \\
\hline & & & & Bulb scale & Basal plate & \\
\hline 51 & Yes & 51 & 8.1 & 66.9 & 73.2 & 0.59 \\
\hline 51 & No & 41 & 5.3 & 65.8 & 70.1 & 0.54 \\
\hline 76 & Yes & 74 & 8.7 & 67.6 & 74.6 & 0.63 \\
\hline 76 & No & 61 & 9.0 & 67.1 & 73.1 & 0.55 \\
\hline LSD $(0.05)$ & & 3 & 1.8 & 1.0 & 2.9 & 0.14 \\
\hline \multicolumn{7}{|l|}{$\mathrm{F}$ tests } \\
\hline Percent water & & $* * *$ & $* *$ & * & * & NS \\
\hline Liner & & $* * *$ & NS & * & $*$ & NS \\
\hline Water $\times$ liner & & NS & $*$ & NS & NS & NS \\
\hline
\end{tabular}

${ }^{\mathrm{z}}$ Average levels at packing were: $9.4 \mathrm{~g}$ fresh weight roots, basal plate water content of $71.4 \%$, bulb scale water content of $63.1 \%$, and meristem diameter of $0.58 \mathrm{~mm}$.

$* * *, * *, *$, NS Significant at $P=0.001,0.01,0.05$, or nonsignificant, respectively.

1) compared $\approx 7 \%$ from peat in nonlined cases. While bulb moisture content at planting was influenced by the initial packing medium water content, the use of a liner did not generally

Table 3. Influence of sphagnum peat moisture level and polyethylene lining during handling and case vernalization on 'Nellie White' Easter lily bulb characteristics 2 weeks after planting (1986-87).

\begin{tabular}{ccccc}
\hline $\begin{array}{c}\text { Initial sphagnum } \\
\text { peat water } \\
\text { content } \\
(\% \text { total wt) }\end{array}$ & $\begin{array}{c}\text { Case } \\
\text { lining }\end{array}$ & $\begin{array}{c}\text { Meristem } \\
\text { diam }^{z} \\
(\mathrm{~mm})\end{array}$ & $\begin{array}{c}\text { New root } \\
\text { fresh wt } \\
(\mathrm{g})\end{array}$ & $\begin{array}{c}\text { Sprout } \\
\text { length } \\
(\mathrm{cm})\end{array}$ \\
\hline 51 & Yes & 0.70 & 1.5 & 5.2 \\
51 & No & 0.64 & 1.5 & 1.8 \\
76 & Yes & 0.69 & 1.6 & 6.0 \\
76 & No & 0.69 & 2.4 & 4.9 \\
LSD (0.05) & & 0.05 & 0.6 & 2.0 \\
F tests & & & & $*$ \\
Percent water & & NS & $*$ & $*$ \\
Liner & & $*$ & NS & $*$ \\
Water $\times$ liner & & $*$ & NS & NS \\
\hline
\end{tabular}

${ }^{z}$ All meristems vegetative at this time.

*,NSSignificant at $P=0.05$ or nonsignificant, respectively. increase the average bulb water content. Sphagnum peat water content alone influenced mean days to emerge, while liner use significantly reduced the spread in days to emerge only with sphagnum peat at $45 \%$ water content. Neither the mean nor spread in days to flower (19-31), flower bud number (Table 1) nor leaf number (89-96) were influenced by the treatments. Liner use increased both stem diameter and basal leaf extension at flowering, regardless of medium water content (Table 1).

1986-87 studies. Liner use reduced water loss from the peat during handling and CV (Table 2). Liner use led to greater growth of roots during handling and $\mathrm{CV}$ when only bulbs were packed in sphagnum peat at $51 \%$ water content. The higher initial sphagnum peat moisture content and lining increased bulb scale and basal plate water content at planting. Differences in meristem diameters were not significant at planting. However, differences were significant 2 weeks after planting (Table 3), when bulbs from lined cases of medium at $51 \%$ water had apical meristems larger than those from unlined cases at the same water content. Lining also increased elongation of the floral sprout from bulbs packed in peat at either water content. Larger meristem diameters resulting from case lining were still maintained 4 weeks after planting (Table 4), but this difference likely was a result of all bulb meristems in PE-lined cases reaching repro-

Table 4. Influence of sphagnum peat moisture level and polyethylene lining during handling and case vernalization on 'Nellie White' Easter lily bulb characteristics 4 weeks after planting (198687).

\begin{tabular}{ccccccc}
\hline \hline $\begin{array}{c}\text { Initial } \\
\text { sphagnum peat } \\
\text { water content } \\
(\% \text { total wt) }\end{array}$ & $\begin{array}{c}\text { Case } \\
\text { lining }\end{array}$ & $\begin{array}{c}\text { Diameter } \\
(\mathrm{mm})\end{array}$ & $\begin{array}{c}\text { Development } \\
\text { stage }\end{array}$ & $\begin{array}{c}\text { Reproductive } \\
(\%)\end{array}$ & $\begin{array}{c}\text { New } \\
\text { root } \\
\text { fresh wt } \\
(\mathrm{g})\end{array}$ & $\begin{array}{c}\text { Plants with } \\
\text { stem roots } \\
(\%)\end{array}$ \\
\hline 51 & Yes & 1.38 & 4.1 & 100 & 5.5 & 35 \\
51 & No & 0.75 & 1.9 & 15 & 6.2 & 0 \\
76 & Yes & 1.34 & 3.7 & 100 & 5.7 & 80 \\
76 & No & 0.96 & 2.9 & 70 & 8.2 & 25 \\
LSD (0.05) & & 0.55 & 0.9 & 22 & 2.3 & 37 \\
F tests & & & & & & \\
Percent water & & NS & NS & $* *$ & NS & NS \\
Liner & & $*$ & $* *$ & $* * *$ & NS & $* *$ \\
Water $\times$ liner & & NS & $*$ & $* *$ & NS & $*$
\end{tabular}


Table 5. Influence of sphagnum peat moisture content and polyethylene lining during handling and case vernalization on forcing characteristics of 'Nellie White' Easter lily bulbs (1986-87).

\begin{tabular}{ccccccc}
\hline $\begin{array}{c}\text { Initial } \\
\text { sphagnum peat } \\
\text { water content } \\
\text { (\% total wt) }\end{array}$ & $\begin{array}{c}\text { Case } \\
\text { lining }\end{array}$ & $\begin{array}{c}\text { Days } \\
\text { to } \\
\text { emergence }\end{array}$ & $\begin{array}{c}\text { Days } \\
\text { to } \\
\text { flower }\end{array}$ & $\begin{array}{c}\text { Basal } \\
\text { leaf } \\
\text { ratingz }\end{array}$ & $\begin{array}{c}\text { Flower } \\
\text { bud } \\
\text { num- } \\
\text { ber }\end{array}$ & $\begin{array}{c}\text { Leaf } \\
\text { number }\end{array}$ \\
\hline 51 & Yes & 18 & 108 & 2.0 & 6.1 & 76 \\
51 & No & 23 & 118 & 2.1 & 6.4 & 79 \\
76 & Yes & 17 & 106 & 2.3 & 5.6 & 73 \\
76 & No & 18 & 111 & 2.2 & 6.5 & 80 \\
LSD (0.05) & & 2 & 3 & 0.8 & 1.2 & 11 \\
F tests & & $* *$ & $* *$ & NS & NS & NS \\
Percent water & & $* *$ & $* *$ & NS & NS & NS \\
Liner & & $*$ & NS & NS & NS & NS \\
Water $\times$ liner & & & & & & \\
\hline
\end{tabular}

${ }^{z}$ See Fig. 1 .

$* * *, * *, *$, Ns Significant at $P=0.001,0.01,0.05$, or nonsignificant, respectively.

ductive stage by this time. The percentage of plants with stem roots at 4 weeks was also greatly increased by case lining, although the total weight of all new roots was not affected. Despite the larger meristems observed 2 weeks after planting, PE lining failed to significantly increase flower bud number (Table 5). Lining did result in decreased days to emerge and flower, with the greatest lining effects from bulbs packed with medium at $51 \%$ water content (Table 5). There were no significant effects on spread of days to emerge (6-10) or flower (9$24)$, or in leaf number (Table 5). Contrary of 1985-86, the appearance of the basal leaves was not influenced by case lining.

1987-88 studies. The temperature of bulbs in unlined cases of sphagnum peat at $68 \%$ water content declined most rapidly. Time to obtain $95 \%$ of temperature decline was $\approx 90 \mathrm{hr}$ in lined cases without medium, $78 \mathrm{hr}$ in lined cases packed with peat, and $54 \mathrm{hr}$ in nonlined cases packed with peat.

No significant differences between water content of scales (63\% to $64 \%)$, basal plates (63\% to $65 \%)$, or apical meristem diameters $(0.62$ to $0.70 \mathrm{~mm})$ of bulbs from the three treatments were found at time of planting. Neither were there significant differences in root rating (1.9 to 2.7$)$, sprout length (1 to $2 \mathrm{~cm}$ ), or meristem diameters (0.66 to $0.70 \mathrm{~mm}$ ) measured 2 weeks after planting. Similar trends continued 4 weeks after planting, with no significant differences in root rating (3.7 to 5.2), sprout length (6 to $9 \mathrm{~cm})$, meristem diameter $(0.65$ to $0.75 \mathrm{~mm})$, or meristem developmental stage (1.7 to 2.3). Use of the PE liner with or without peat reduced days to visible buds, days to flower, and total leaf number compared to unlined cases packed with peat at $68 \%$ water content (Table 6). PE lining had no significant influence on days to emergence, basal leaf rating, bud number (Table 6), or in spread in days to emerge (12 to 14$)$ or flower (12 to 18$)$. Within the two treatments with lined cases, packing with sphagnum peat at $29 \%$ water resulted in no significant differences in forcing characteristics from bulbs packed with no medium (Table 6).

\section{Discussion}

While there were differences in treatments and in bulb responses over 3 years, many general conclusions can be drawn from these studies. Packing bulbs in sphagnum peat at elevated moisture levels or lining of cases with PE increases the response of the bulbs to the cold treatment. In agreement with Stuart (1954), we observed accelerated flowering as a result of case lining in 1986-87 and 1987-88 (Tables 5 and 6). A similar trend from lining of cases packed with sphagnum peat at $45 \%$ water was evident in 1985-86, but was not statistically significant (Table 1). In addition to earlier flowering, we observed longer sprouts 2 weeks after planting (Table 3) and accelerated sprout emergence (Table 5) in 1986-87. A similar trend was seen in 1985-86, but was not statistically significant (Table 1). Bulbs in lined cases reached reproductive stage earlier than those in nonlined cases in 1986-87 (Table 4), and there was a large reduction in leaf number from case lining regardless of presence of peat in 1987-88 (Table 6). All of these observations support increased response to cold by the bulbs.

A direct effect on bulb scale moisture content is a likely reason for the enhanced cold response. The bulb scales are believed to be the site of hormonal response to vernalizing temperatures (Lin and Roberts, 1970). In 1986-87, a 1\% difference in final bulb scale moisture content between bulbs in lined and nonlined cases of peat at $51 \%$ moisture (Table 2) resulted in a difference of 10 days to flower (Table 5). For bulbs packed in peat at $76 \%$ moisture, lining resulted in a $0.5 \%$ difference in bulb scale moisture content (Table 2), and a difference of 5 days to flower (Table 5). These results suggest about a 10-day acceleration in time to flower for each $1 \%$ increase in bulb scale water content. More data over a wider range of moisture contents will be necessary to confirm this relationship.

Stuart (1954) reported increased flower numbers from PE case lining, an observation we were unable to duplicate. Perhaps the lower vernalization temperature $(0 \mathrm{C})$ that he used influenced this response. The larger stem diameters at flowering obtained

Table 6. Influence of packaging medium, medium moisture level, and polyethylene (PE) lining during handling and case vernalization on 'Nellie White' Easter lily bulb forcing characteristics (1987-88).

\begin{tabular}{|c|c|c|c|c|c|c|c|c|}
\hline \multirow[b]{2}{*}{$\begin{array}{l}\text { Case } \\
\text { lining }\end{array}$} & \multirow[b]{2}{*}{$\begin{array}{c}\text { Packaging } \\
\text { medium }\end{array}$} & \multicolumn{2}{|c|}{ Water content } & \multirow{2}{*}{$\begin{array}{c}\text { Days } \\
\text { to } \\
\text { emergence }\end{array}$} & \multirow{2}{*}{$\begin{array}{l}\text { Days } \\
\text { to } \\
\text { flower }\end{array}$} & \multirow{2}{*}{$\begin{array}{c}\text { Basal } \\
\text { leaf } \\
\text { rating }\end{array}$} & \multirow{2}{*}{$\begin{array}{l}\text { Flower } \\
\text { bud } \\
\text { number }\end{array}$} & \multirow[b]{2}{*}{$\begin{array}{c}\text { Leaf } \\
\text { number }\end{array}$} \\
\hline & & $\begin{array}{c}\text { Initial } \\
(\% \text { total wt })\end{array}$ & $\begin{array}{c}\text { Final } \\
(\% \text { total wt })\end{array}$ & & & & & \\
\hline \multirow[t]{2}{*}{$\overline{\text { Yes }}$} & Sphagnum peat & 29 & 34 & 29 & 110 & 2.2 & 7.1 & 75 \\
\hline & None & - & -- & 25 & 108 & 2. & 6.5 & 76 \\
\hline No & Sphagnum peat & 68 & 62 & 27 & 117 & 2.5 & 7.1 & 95 \\
\hline \multicolumn{2}{|c|}{$\operatorname{LSD}(0.05)$} & & 3 & 7 & 9 & 0.5 & 1.5 & 10 \\
\hline \multicolumn{9}{|c|}{$\mathrm{F}$ tests } \\
\hline \multicolumn{2}{|c|}{ Liner vs. no liner } & & $* * *$ & NS & $*$ & NS & NS & $* *$ \\
\hline \multicolumn{3}{|c|}{ Within liner, peat vs. none } & $\cdots$ & NS & NS & NS & NS & NS \\
\hline
\end{tabular}

${ }^{z}$ See Fig. 1.

$* *, *$, Ns Significant at $P=0.001,0.05$, or nonsignificant, respectively. 
from bulbs from lined cases in 1985-86 (Table 1) prompted our further study of apical meristem responses in subsequent years. Lining of cases packed with sphagnum peat at $51 \%$ water enhanced meristem diameter measured 2 weeks after planting, but before floral initiation (Table 3). Despite the larger meristem, flower bud count was not significantly influenced by treatments in this or any of our studies. This lack of response suggests that sampling of meristem diameter over time only reflected an accelerated forcing response, and not an increased potential for flower bud development, as has been observed for meristem diameters of the bulbs at harvest (De Hertogh et al., 1976). Use of different forcing temperature regimes than we used could possibly have resulted in increased flower bud counts from the larger meristem (De Hertogh et al., 1976; Roh and Wilkins, 1977).

The greater water content of basal plates of bulbs packed in lined cases failed to result in greater root development during the first 4 weeks after planting (Tables 3 and 4). However, some enhancement of root growth from bulbs during handling and vernalization in lined cases was observed (Table 2). Enhanced growth of roots in lined cases could have influenced the response of the bulbs to cold. The presence of actively growing roots on bulbs undergoing CTF has been proposed as a possible reason for their superior forcing characteristics compared to bulbs from CV (De Hertogh et al., 1969). CTF results in plants with more flowers and leaves as well as longer basal leaves than bulbs programmed by CV (De Hertogh and Wilkins, 1971a, 1971b). However, we did not obtain more flowers and leaves and only obtained longer basal foliage from case lining in 198586 (Table 1). Enhanced growth of roots during handling and vernalization could be problematic on a commercial basis if it becomes excessive. The early presence of stem roots in 198687 on bulbs from lined cases (Table 4) was likely caused by the early development of reproductive meristems, since these two events were related in commercial observations. Therefore, we conclude that faster root system establishment after planting is an unlikely cause of the accelerated forcing response of bulbs from PE-lined cases, but that increased root growth on bulbs while in the cases may influence their response to cold.

Differences in the observed rate of temperature decline of bulbs at the beginning of $\mathrm{CV}$ is an unlikely cause of the bulb resposes to case lining. Bulbs in lined cases packed without medium had the slowest decline in temperature of the three treatments in 1987-88 (Fig. 2), but required the fewest days to flower (Table 6). The slower rate in temperature decline was likely due to reduced conduction of heat from the bulbs to the case exterior, due to lack of physical medium between the bulbs. Bulbs in nonlined cases declined in temperature the most rapidly of the three treatments, but required the most days to flower (Table 6). Since increased duration of cold exposure is known to accelerate forcing (De Hertogh and Wilkins, 1971a, 1971b), the effects of lining would have been opposite to that observed if the primary effect of lining was on temperature decline. This result again indicates that the influence of bulb water content on sensing of the cold period was more important than minor influences of the packing or lining on actual rate of temperature decline during $\mathrm{CV}$.
The benefits of case lining were most pronounced with peat at the lower initial water contents, where moisture loss from nonlined cases may have limited the vernalization of the bulbs. Therefore, commercial usage of PE lining of bulb cases packed with sphagnum peat should allow a reduction of peat water contents, thus reducing shipping weights and lowering the possibility of overly wet peat increasing rots or other disorders (Stuart, 1954). Our studies indicate that prevention of water loss from the bulbs by case lining alone can lead to acceptable forcing. There were no disadvantages from excluding peat from the lined cases based on the forcing characteristic we observed (Table 6). Commercial trials need to be performed before widespread use of this method is adopted. Costs could be reduced by eliminating sphagnum peat usage, and reducing shipping weights by $15 \%$ to $20 \%$. This technique could further lower the risk of bulb rots and could aid the development of mechanized packing. Bulb moisture levels before packing could be critical to the success of this technique, and should be studied.

\section{Literature Cited}

Blaney, L.T. and A.N. Roberts. 1967. Influence of harvest date and precooking on leaf and stem elongation in the "Croft" Easter lily (Lilium longiflorum Thunb.). J. Amer. Soc. Hort. Sci. 89:651-656.

De Hertogh, A.A. 1985. Holland bulb forcers guide. Intl. Flower Bulb Center, Hillegom, The Netherlands.

De Hertogh, A.A., W.H. Carlson, and S. Kays. 1969. Controlled temperature forcing of planted lily bulbs. J. Amer. Soc. Hort. Sci. 94:433-436.

De Hertogh, A A., H.P. Rasmussen, and N. Blakely. 1976. Morphological changes and factors influencing shoot apex development of Lilium longiflorum Thunb. during forcing. J. Amer. Soc. Hort. Sci. 101:463-471.

De Hertogh, A.A. and H.F. Wilkins. 1971a. The forcing of northwestgrown 'Ace' and 'Nellie White' lilies. Part 1. Flor. Rev. 149(3857):2931 .

De Hertogh, A.A. and H.F. Wilkins. 1971b. The forcing of northwestgrown 'Ace' and 'Nellie White' lilies. Part 2. Flor. Rev. 149(3858):104-111.

Laiche, A.J. and C.O. Box. 1970. Response of Easter lily to bulb treatments of precooking, packing media, moisture and gibberelin. HortScience 5:396-397.

Lin, P.C. and A.N. Roberts. 1970. Scale function in growth and flowering of Lilium longiflorum Thunb. 'Nellie White'. J. Amer. Soc. Hort. Sci. 95:559-561.

Rob, S.M. and H.F. Wilkins. 1977. Temperature and photoperiod effect on flower numbers in Lilium longiflorum Thunb. J, Amer. Soc. Hort. Sci. 102:235-242.

SAS Institute. 1982. SAS user's guide: Statistics. SAS Institute, Inc. Cary, N.C.

Stuart, N.W. 1954. Moisture content of packing medium, temperature, and duration of storage as factors in forcing lily bulbs. Proc. Amer. Soc. Hort. Sci. 63:488-494.

Wilkins, H,F. 1976. Methods and schedules for forcing Easter lilies1977, a late Easter. Minn. State Flor. Bul. Oct. p. 3-5.

Wilking, H.F. 1977. Methods and schedules for forcing Easter lilies1978, an early Easter. Minn. State Flor. Bul. Oct. p. 2-4.

Yang, S.Y., A.N. Roberts, and L.T. Blaney. 1970. Relationship between length of vernalization, stem apex size, and initiatory activity in Lilium longiflorum cv. 'Ace'. HortScience 5:113-114. 